\title{
EL PROYECTO DE UN SUJETO ENTRE LO SAGRADO Y LO PROFANO EN LA NOVELA LUMINOSA DE MARIO LEVRERO
}

\author{
POR \\ Christina Soto van der Plas \\ Cornell University
}

En un fragmento de La novela luminosa (2005) titulado "Primera comunión" el autor uruguayo Mario Levrero (1940-2004) cuenta que conserva una única imagen nítida del periodo de tiempo en el que, luego de su bautizo, lo obligaban a ir a la escuela dominical. La imagen que recuerda es la manera en que su zapato derecho, fabricado con algún tipo de "materia perversa" y con una forma "diabólicamente puntiaguda", trazaba un dibujo en el respaldo del asiento frente al suyo y ese contacto producía un áspero sonido (524). Más allá de la impresión visual el hecho es que el autor creía que sólo él era capaz de escuchar el sonido que este movimiento producía, pues dice, "retumbaba en el recinto la voz de algún ser para mí invisible situado allá adelante" (524). A pesar de que no llega a escuchar ninguna palabra ni a entender, el narrador dice haber oído ese sonido que de alguna manera le estaba destinado y le comunicaba que había algo más allá de lo visible. La escena trivial de la forma y materiales de los que estaba hecho el zapato y el trazo del dibujo en el asiento de enfrente no tienen ninguna significación por sí mismos y sólo forman parte de la experiencia cotidiana del narrador. Lo descrito concretamente en la imagen pertenece a la esfera de lo cotidiano, lo profano, lo repetitivo. No obstante, tanto la adjetivación del narrador al hablar de la materia "perversa" y de la forma "diabólicamente" puntiaguda del zapato como el que lo coloque en una sección llamada "Primera comunión" señala que hay algo fuera de lo común en lo que describe y eso predice que no son gratuitos los elementos descritos, sino que son parte de una experiencia que resulta inexplicable, excepcional, o sagrada. Escuchar la voz de un ser invisible es un acontecimiento cuya ocurrencia no se deriva o explica solamente mediante los elementos dados, es decir, el zapato y el asiento. La experiencia contenida en la imagen trasciende lo que compone la imagen misma.

El ir y venir de, por un lado, la descripción obsesiva de lo cotidiano y, por otro, la experiencia inexplicable del contacto con lo trascendental es una operación central de la visión literaria de Mario Levrero. Para Levrero, la literatura es el proceso estético mediante el cual la vida y la experiencia tanto de lo cotidiano como de lo trascendental se vuelven significativos al ser elaborados y relatados. A su vez, como resultado de 
este proceso se conforma una subjetividad que parte de la escritura. En este sentido, en esta imagen de "Primera comunión" la experiencia del sonido es para el narrador una vivencia que, al integrarse en su colección de imágenes "luminosas", conforma su subjetividad dado que para Levrero un sujeto es un cúmulo de instantes significativos. El narrador se ve transformado por ese instante en el que al hacer su zapato contacto con el asiento, retumba una voz en forma de puro sonido sin origen. Es una suerte de "instante privilegiado" que se encuentra en el azar de la búsqueda (Bataille, "Sagrado" 264), en medio de lo cotidiano. Y la voluntad de fijar estos instantes privilegiados con el objetivo de hacerlos reaparecer en el proyecto de una novela es la meta de La novela luminosa. Durante la parte tardía de su producción, frecuentemente denominada como su etapa "autobiográfica", ${ }^{1}$ Levrero concibe su literatura como el punto de encuentro entre lo profano y lo sagrado, así como la manera en que la experiencia de este encuentro crea una subjetividad y por lo tanto un cierto tipo de escritura que no puede regirse por los mecanismos tradicionales de la narrativa. En vez de armar una trama tradicional con lógica interna o de narrar en una cierta temporalidad y espacio, a partir de personajes, Levrero narra la deriva y el deseo mismo de escribir, ya sea sus obsesiones cotidianas o los momentos que denomina "luminosos", así como sus encuentros. Por ello, esta primera imagen de la experiencia del sonido de un "ser invisible" ya señala la manera en la que la literatura del autor uruguayo opera en una búsqueda constante del ámbito de la experiencia de los instantes privilegiados o luminosos de lo sagrado, manteniendo una conexión íntima con los elementos necesarios para llegar a esa esfera de difícil acceso y de aún más difícil comunicabilidad mediante la literatura.

En la sección "La novela luminosa"" lo sagrado se concibe no como un producto final o un objeto, sino como una búsqueda constante de ciertas instancias o imágenes luminosas que se separan de lo cotidiano o profano por su significación y cualidad de provocar una ruptura radical en la percepción tradicional. El proyecto de la novela consiste en la indagación de toda la serie de elementos experienciales que han sido clasificados por el narrador como luminosos y que van llenando el "espacio vacío de lo sagrado" (Žižek, Most Sublime 116) con imágenes colmadas de significación simbólica. Por ello, en el presente ensayo propongo que La novela luminosa de Mario Levrero plantea que el acceso a lo sagrado sólo es posible mediante la articulación del sentido y las imágenes de lo profano y cotidiano. A su vez, este vínculo sólo se articula cuando se produce y transforma la literatura en experiencia de vida, en parte de una subjetividad. En La novela luminosa se estructura un sujeto capaz de construirse a sí mismo en el cruce de lo sagrado y lo profano mediante el acto de la escritura. La

1 Entre otros Astutti (202) y Laddaga (225) resaltan el carácter autobiográfico de los últimos libros de Levrero.

2 Para diferenciar la sección y la obra entera, escribiré entre comillas la sección: "La novela luminosa", y con itálicas la obra completa: La novela luminosa, que también incluye el "Diario de la beca".

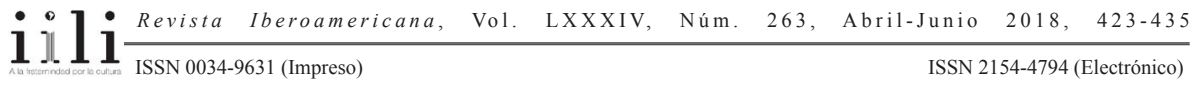


articulación de ambas esferas es lo que le permite funcionar a la literatura de Levrero como un vaivén que articula el deseo y el deber de escribir como procedimientos que, al mismo tiempo, retrasan y van más allá de la meta del proyecto. El narrador desea contar su experiencia de lo sagrado y debe por lo tanto someterse a la difícil disciplina de escribir. Este supuesto objetivo de lo que el narrador debe y desea escribir funciona gracias a la imposibilidad estructural de ser alcanzado. En vez de ello, el narrador desplaza su movimiento a la escritura de una subjetividad que se va conformando en el desvío y proceso de la narración. Si lo sagrado es una esfera compuesta de manera diferencial con respecto a lo profano (Žižek, "God Without”"15), para Levrero la escritura de las experiencias luminosas constituye el núcleo de un tipo de literatura que crea un sujeto precisamente porque implica que debe estar incluido en una configuración estética cuya distribución y efectos se vuelven parte de su vida.

\section{LO PROFANO Y LA BÚSQUEDA DE LO SAGRADO}

Publicada de manera póstuma, La novela luminosa es un texto dividido en dos partes: el largo prólogo de cuatrocientas cincuenta páginas titulado "Diario de la beca"y la breve "La novela luminosa". En "Diario de la beca", el narrador relata sus actividades diarias, su rutina y sus persistentes obsesiones y manías. Entre sus obsesiones, se puede leer sobre el cadáver de un pájaro que apareció afuera de su ventana, la manera en que pierde el tiempo con su compulsión de jugar ciertos juegos en la computadora y con diseñar un software que le recuerde tomar sus medicinas a tiempo, las vicisitudes de su fallida relación amorosa y en decadencia con Chl, la manera en que gasta su dinero y tiempo de ocio preparando la "novela" para cuya escritura le dieron una beca, entre otras cosas. "Diario de la beca" tiene como propósito "poner en marcha la escritura, no importa con qué asunto, y mantener una continuidad hasta crear el hábito" (La novela 23). De esta manera, el narrador se impone a sí mismo el deber de escribir algo cada día, sin importar qué sea, incluso si, algunos días, sólo le es posible escribir que no tiene nada que decir. El registro de lo que sucede día a día y el intento de llegar a un sentido profundo, como dice Sergio Chejfec (193), constituyen los mecanismos que impulsan el acto de la escritura.

Todo el esfuerzo contenido en el "Diario de la beca" es una práctica preliminar para finalmente llegar a escribir "La novela luminosa" para cuya culminación el autor ganó una beca Guggenheim. No obstante, al tiempo que se plantea en el diario que esta suerte de ejercicio de anotar lo cotidiano está diseñado para lograr completar la novela, el esfuerzo de la escritura no progresa hacia su objetivo y en vez de eso la vida del narrador se vuelve el objeto del relato, en forma de diario cronológico. Al mismo tiempo, se mantiene una circulación obsesiva y postergación alrededor del objeto real del texto, es decir, la "novela" prometida para la cual todo se prepara y dispone. El

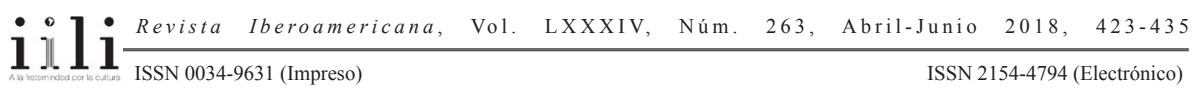


fin sucede en el medio en tanto la perpetuamente desplazada escritura de la novela resulta en otro tipo de búsqueda: "el retorno al yo". Este retorno al yo, el "retorno a mí mismo" (Novela luminosa 38) es considerado por el narrador el medio a través del cual, a la larga, llegará al núcleo de lo que necesita escribir, las imágenes luminosas trascendentes. Pero en verdad este retorno, el círculo reflexivo del movimiento del sujeto hacia sí mismo es un proceso que consciente y explícitamente representa sus propias condiciones de posibilidad y es más que una herramienta de escritura. Esta representación autoconsciente implica por entero la constitución del sujeto y no sólo es parte de un esfuerzo cognitivo en busca de conocimiento; es, de muchas maneras, una indagación acerca de la especificidad del discurso literario como conocimiento autobiográfico espiritual, en busca constante de la excepcionalidad de una verdad sagrada.

Tan esperada y planeada, "La novela luminosa" colocada justo después del "Diario de la beca" no es una narrativa tramada y coherente, sino que es una serie de imágenes con reflexiones sobre estas imágenes y su importancia dentro del proyecto. No es posible establecer cuál es la historia principal, ya que no hay una secuencia ni concatenación de acontecimientos. Incluso se puede decir que en la novela hay sólo acontecimientos. Además, estos acontecimientos no están atados a ningún tipo de contexto o sitio, ni al lugar, tiempo y circunstancias donde suceden, por lo que funcionan como un catálogo o lista de acontecimientos coleccionados sin relación el uno con el otro, excepto su cualidad de ser considerados "luminosos" por el narrador. Estos acontecimientos, entonces, se representan mediante imágenes e impresiones sensoriales. Lo que el autor denomina "momentos luminosos" son en realidad "momentos autobiográficos" (Novela luminosa 456) que se podrían calificar como profanos y triviales. Los momentos autobiográficos incluyen, por ejemplo, el momento en que el narrador nota que un perro estaba oliendo en el pasto el rastro de una perra no solamente en busca de su olor, sino comportándose como si estuviera frente al objeto mismo, o la descripción de un papel particularmente grueso en el que está escribiendo que resulta ser un regalo de parte de una mujer que lo robó de su oficina al enterarse de las dificultades económicas del autor.

El narrador reconoce y relata estos acontecimientos "trascendentes" y les da un significado con el propósito de tejerlos en una novela, es decir, como una serie de imágenes significativas y que deben crear un sentido, tejidas progresivamente para provocar una sensación de éxtasis, un clímax y en última instancia llegar a un final. Las imágenes, incluso si son triviales, marcan para el autor momentos en los que se encontró con la eternidad y hay un "aplazamiento de la existencia" (Bataille, Experiencia interior 73). Las imágenes son momentos atemporales capturados a través de impresiones. Sin embargo, el momento culminante, en el que se supondría que el sujeto llegaría a sentirse y a estar completo al encontrarse a sí mismo en el extático momento luminoso, nunca llega en la novela porque, de acuerdo con el narrador, hay una imposibilidad inherente de narrar las imágenes luminosas. El narrador explica que en el momento

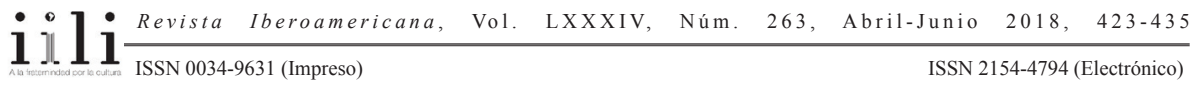


en el que se traman las imágenes y se declara que son significativas, pierden su lustro, decepcionan y suenan triviales (Novela luminosa 19). De esta manera, el intento de construir un yo ideal completo y no dividido en el discurso, como resultado de narrar imágenes trascendentes se ve frustrado por la estructura secuencial del lenguaje y la narrativa. Por ello, la construcción de una subjetividad es un proceso cumulativo de encuentros con lo trascendente que iluminan la visión global del narrador.

Es a través de la narración de imágenes triviales y profanas, no obstante, que el narrador de La novela luminosa concibe la forma autobiográfica que debe tomar su escritura. No una escritura autobiográfica "con todas las de la ley" porque sería "el libro más soso que pudiera escribirse" y cuyo contenido sería "una sucesión de días grises desde la infancia hasta este instante, con esos dos o tres chispazos o relámpagos o momentos luminosos" (Novela luminosa 465). Pero la novela tampoco podría consistir únicamente en "momentos luminosos, contados en forma aislada, y con el agravante de los pensamientos que necesariamente los acompañan" y que "se parecerían muchísimo a un artículo optimista del Selecciones del Reader's Digest” (465). La forma autobiográfica sui géneris de la que habla Levrero es una mezcla de la gris sucesión de momentos profanos y su experiencia de instantes sagrados. Sin la estructura repetitiva de los días grises no tendría ningún significado la luminosidad de ciertos momentos y sin la visión privilegiada desde los relámpagos, de nada valdría contar el día a día. A su vez, la combinación de ambos elementos es lo que para el autor uruguayo conforma la narración y creación de una subjetividad mediante la escritura. La novela luminosa es el modelo de esta escritura autobiográfica peculiar, en su búsqueda de conformar un tipo de literatura que integre lo profano y lo sagrado y de esa manera logre articular un tipo de novela que no sólo refleje la realidad, sino que elabore los momentos grises y luminosos para representar y escribir las maneras en que la literatura también forma parte de la propia realidad.

\section{EL DESEO Y EL DEBER DE LA ESCRITURA}

La premisa de La novela luminosa es el "deber escribir" como resultado de una imposición, una demanda. La demanda proviene en este caso de un amigo que le pide al narrador que escriba una experiencia extraordinaria que le contó durante una conversación. Además de esto, también hay una necesidad concreta de parte del narrador de mostrarle algún resultado a la Fundación Guggenheim por la beca que recibió para el proyecto de "La novela luminosa". La escritura del texto surge de lo que se podría llamar un imperativo ético. Este imperativo es la demanda inicial a partir de la cual surge el deseo. Para Levrero hay una dualidad que funciona en la escritura y que crea una relación dialéctica entre un cierto deber y el deseo mismo. Al hablar sobre la oposición entre la novela oscura y la novela luminosa, los dos caminos posibles del proyecto 
que está tramando, dice: "Ahora debo escribir (la novela oscura) y deseo escribir (la novela luminosa), pero no sé cómo hacerlo. Se ha fugado de mí el espíritu travieso, alma en pena, demonio familiar o como quiera llamársele, que hacía el trabajo en mi lugar. Estoy a solas con mi deber y mi deseo" (465).

La novela oscura ${ }^{3}$ y la novela luminosa funcionan como dos caras de la misma moneda. En la novela oscura, lo que está en juego es el deber de escribir a partir de un incondicional "debo": la novela debe ser escrita. Por otro lado, en la novela luminosa hay un deseo de escribir, de suprimir la brecha que separa la escritura del objeto que le falta, es decir, el relato de "dos o tres chispazos o relámpagos o momentos luminosos" (465). Sin embargo, la manera específica en la que esto pueda suceder es incierta para el narrador, pues cree que el impulso de escribir proviene de la momentánea rendición de su voz para darle su voz a otro "yo", "el que hacía el trabajo en mi lugar", ya sea un juguetón espíritu travieso o un alma en pena demoniaca. Lo que resta es un solitario "yo" que se encuentra a solas con su deber y su deseo. Los roles del sujeto se reducen a estas dos maneras básicas de relacionarse con el mundo y al mismo tiempo este "yo" constantemente busca su propia estructura y ser en su deber y deseo. Es por eso que el deber inicial de escribir implica desde un principio el deber de un "retorno a un yo" perdido, a partir de donde surge el deseo de escribir "La novela luminosa".

En el prólogo de La novela luminosa el narrador confiesa estar confundido en relación a cuál fue el impulso inicial que lo llevó a comenzar la escritura de la novela. Dice recordar que todo comenzó con una imagen que surgió en la antes mencionada conversación que tuvo con uno de sus amigos. Pero, al mismo tiempo, cuando relee el primer capítulo de "La novela luminosa" se da cuenta de que había escrito que otra imagen obsesiva motivó la escritura de la novela. ${ }^{4}$ Desde el inicio, hay un origen doble del proyecto de la novela. Es importante notar que se trata de un proyecto y no necesariamente de una novela como producto acabado pues el producto final no es lo importante, sino todo el proceso en busca de ese objeto deseado. La primera de estas dos imágenes que dan origen al proyecto es la disposición especial y arreglo de los elementos necesarios para la escritura; ${ }^{5}$ y la segunda, es la escritura de ciertas

3 En una conversación posterior, Levrero dice que su "novela oscura" fue finalmente publicada bajo el título de Desplazamientos (Levrero, Un silencio 32).

4 En un comentario irónico, Levrero dice que: "una novela actualmente, es casi cualquier cosa que se ponga entre tapa y contratapa" (Novela luminosa 26). De tal forma que se puede decir que la categoría de la "novela" no tiene contenido y su única condición es que esté contenida dentro de los límites de dos tapas. Esto le da la libertad a Levrero de llenar el significante vacío de "novela" con su propio discurso.

5 En "Diario de un canalla", Levrero sugiere la que podría ser la imagen: "Cuando comencé a escribir aquella novela inconclusa, lo hice dominado por una imagen que me venía persiguiendo desde hacía cierto tiempo: me venía escribiendo algo -no sabía qué- con una lapicera de tinta china, sobre un papel de buena calidad" (20). 
experiencias que pueden ser catalogadas como luminosas (14). Estas dos imágenes son también las dos vetas de la novela: el "Diario de la beca" y "La novela luminosa". "Diario de la beca" es un intento neurótico de desplegar, reflexionar y obsesivamente disponer los materiales necesarios para la escritura con la intención de finalmente llegar a escribir "La novela luminosa". "La novela luminosa", por su parte, es el antes mencionado catálogo de experiencias luminosas exhibidas en una suerte de inventario sin relación de causa y efecto entre los elementos. Es posible decir que al buscar una causa, el narrador trata de explicar y darle coherencia a los efectos, que parecen ser una serie de imágenes y sucesos repetitivos sin relación los unos con los otros y sin propósito ulterior, para cohesionar su esfuerzo literario en un proyecto con significado.

El siguiente pasaje de La novela luminosa es parte del inicio de la novela en donde, como mencioné antes, el narrador dice que uno de sus amigos le impuso el deber de escribir la historia, sabiendo de antemano que era imposible plasmar y representar la experiencia que le relató:

Me llama la atención que ahora, pasado mucho tiempo, vea tan claramente la relación causa-efecto: mi amigo me impulsó a escribir una historia que yo sabía imposible de escribir, y me lo impuso como un deber; esa imposición quedó allí, trabajando desde las sombras, rechazada de modo tajante por la consciencia, y con el tiempo comenzó a emerger bajo la forma de esa imagen obsesiva, mientras borraba astutamente sus huellas porque una imposición genera resistencias; para eliminar esas resistencias $l a$ imposición venida desde afuera se disfrazó de un deseo venido desde adentro. Aunque, desde luego, el deseo era preexistente [...] tal vez supiera de un modo secreto y sutil que mi amigo buscaría la forma de obligarme a hacer lo que yo creía imposible. Lo creía imposible y lo sigo creyendo imposible. Que fuera imposible no era un motivo suficiente para no hacerlo, y eso yo lo sabía, pero me daba pereza intentar lo imposible. (énfasis mío, 14)

A pesar de lo mucho que el narrador intenta borrar las huellas del deber impuesto, los residuos de la demanda que se le impuso regresan para perseguirlo, articulados como deseo de escribir. Se asume la contingencia como causa, es decir, el momento en el que el amigo del narrador demandó la escritura de la historia resulta ser lo que en primer lugar pone en movimiento la escritura y es lo que retroactivamente parece haber lanzado la cadena metonímica del deseo. ${ }^{6} \mathrm{Al}$ principio, como dice el narrador

${ }^{6}$ Por metonímica me refiero a que hay un constante desplazamiento de significantes que reconfiguran la dinámica teleológica del significado, como por ejemplo, en la cambiante idea de cómo y qué será la novela y la forma que tomará. El autor debate en el texto acerca de la forma novelística constantemente y se pregunta, “¿tendría que ser, pues, un ensayo? Me resisto a la idea” (Novela luminosa 455); puede ser una "lista mental de experiencias que quería dejar escritas como testimonio, antes de enfrentar el bisturí" (464) o la narración de una anécdota "(la pertinencia de cuya inserción en esta novela luminosa

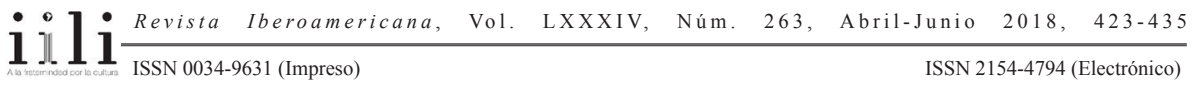


en la cita, el deber es rechazado sólo para, más adelante, regresar disfrazado de deseo "venido desde adentro". El deseo no es el "origen" de la novela, sino que es creado retroactivamente como un a priori del deber impuesto y a partir del cual la necesidad de escribir se desarrolla. Al decir que cualquier demanda o imposición genera resistencias y tales fuerzas se graban en imágenes, el narrador quiere explicar el carácter obsesivo de la imagen que sigue regresando a su conciencia. Y la imposibilidad de escribir la imagen parece deberse a su naturaleza, que es un cúmulo de deseos reprimidos que sólo pueden regresar en forma de algo diferente a una imagen narrable. A pesar de todo esto, el narrador se dispone a intentar lo imposible, incluso si este intento no se verá frustrado por la enorme imposibilidad de satisfacer su deseo de narrar, sino más bien por su pereza.

El resultado es una narrativa constantemente frustrada, siempre detenida por esas "resistencias a la imposición" únicamente capaces de generar un pequeño catálogo de imágenes luminosas. En muchos sentidos, el deseo de escribir la novela sólo surge cuando el narrador se apropia de la imposición externa. Es el sujeto el que se apropia del deber externo y lo interioriza y por el que luego tiene que responder. Este es uno de los principios de lo que llamé imperativo ético; para llegar a ser un imperativo tiene que ser complementado por el acto del sujeto. No es que el deber de escribir la novela funcione como una ley previamente establecida, sino que funciona sólo cuando el sujeto se entrega y responde a este deber.

El deber consiste, entonces, en escribir una imagen y a partir de tal necesidad surge el deseo de escribir la novela. El narrador se da cuenta de que había un deseo preexistente en el proyecto de "La novela luminosa" y esto marca la manera en la que lee todo el proyecto como parte de su propia construcción subjetiva. Dice que vive para la novela y que su vida se ha vuelto, al escribir la novela, un monólogo ininterrumpido que ya no depende de su voluntad. Es por esto que habla de "la imposición del trabajo que debo realizar -quiéralo o no- con la única, borrosa esperanza de llegar algún día a un punto final, quedar vacío, exhausto, limpio" (480). El deber se relaciona íntimamente con el yo, con un trabajo muy concreto que el yo debe realizar para lograr su objetivo y completar el proyecto. No obstante, como Levrero dice más adelante, llegar a obtener el objeto del deseo y completar el proyecto es en este caso imposible, dado que no se trata únicamente de un esfuerzo literario, sino que está íntimamente relacionado con la construcción de su subjetividad. Llegar al final significaría la muerte pues para él "eso

sigue siendo para mí un elemento de duda), pero [...] la imagen sigue viniendo obsesivamente [...] aparentemente, no tiene relación con el tema de la novela" (469). El significante de lo que la novela es, debería ser y está siendo se desplaza constantemente y sigue la eternamente cambiante ley metonímica de la dinámica del deseo.

7 En el que considero el mejor artículo escrito hasta ahora sobre La novela luminosa, Gabriel Inzaurralde argumenta que la novela tiene tres ejes que son las experiencias luminosas, la melancolía del día a día y la muerte (1046).

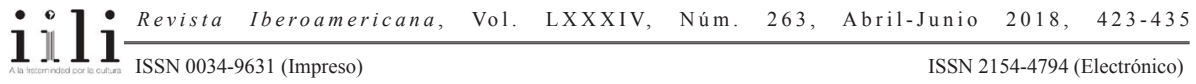


sólo se alcanza con la muerte" (480) y sería el momento en el que el deseo se detiene y en el que podría decir finalmente que completó el proyecto literario-subjetivo. Es por eso que ninguna de las experiencias luminosas lo ha podido llevar a decir “"ya está', 'ya llegué', 'era esto"' (480).

En vez de ello, siempre está intentando narrar una imagen más, otra experiencia luminosa, o narrarla de manera diferente. La meta se plantea solamente como un horizonte inalcanzable de culminación. Incluso si se aproxima y narra sus experiencias como objetos de su deseo o, por ejemplo, el largo calvario que tuvo que pasar para estar con una mujer, la naturaleza del proyecto es funcionar como una cadena de deseos desplazados. Por ejemplo, cuando narra el momento luminoso en el que una joven mujer lo miró, no describe la imagen de la mujer ni sus ojos, sino la cualidad inefable de su mirada que guarda en su memoria. Dice que su mirada ya no tiene propietario y no está sujeta al espacio o tiempo y que de hecho no le pertenece a la mujer, no es parte de su ser (475). Así, parece que lo que impulsa al narrador a seguir escribiendo es la búsqueda de estas instancias en donde lo único que encuentra es su propio vacío: al final, como se citó antes, está exhausto y vacío. Esto sólo confirma que el vacío constitutivo de lo sagrado del que habla Hegel (Žižek, Most Sublime 116) es de donde parte la búsqueda y no donde culmina.

\section{LA CONSTITUCIÓN DEL SUJETO}

A pesar del vacío ulterior, Levrero sabe llenar con mil y una imágenes de vital importancia ese espacio. Los acontecimientos o encuentros narrados en "La novela luminosa" son determinantes para la transformación del sujeto que emerge a partir de la narración de estas instancias. Constantemente, el narrador le recuerda al lector que lo que está leyendo es una operación vital y que debe seguir escribiendo: "debía continuar, porque me resultaba vital averiguar esas verdades que estaba descubriendo" (Novela luminosa 508). Lo que el narrador busca es el descubrimiento de verdades que lo transformen y lo constituyan como sujeto. Y las verdades con las que se encuentra en diferentes instancias en las que experimenta un instante atemporal modifican por completo su "estructura de valores, o de jerarquías" (524). Los momentos luminosos que recuerda se representan en imágenes que forman parte de una lista de otras imágenes trascendentales que muestran un encuentro con lo atemporal. En este caso lo atemporal o lo eterno no se refiere a la incesante circulación del tiempo, sino a algunos momentos fuera de lo ordinario en los que el sujeto se encuentra consigo mismo, donde la circularidad aparece y se vuelve tangible en el encuentro de dos temporalidades, hecho que constituye al acontecimiento en sí. Estos encuentros afectan tanto al pasado como al futuro, agujerean el tiempo, son momentos atemporales y como tales sólo pueden ser narrados en imágenes y no como hilos de una trama.

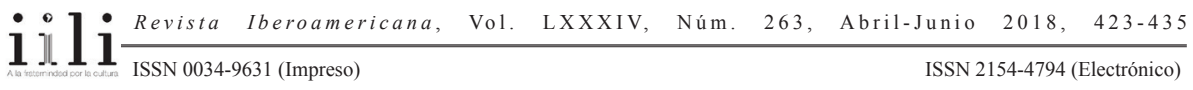


Las instancias luminosas no pueden ser derivadas de las anécdotas que el narrador cuenta, sino más bien de lo que es revelado a manera de una imagen "simultáneamente en mí" (521). En esos momentos hay una percepción mística, sagrada. Michel de Certeau describe este tipo de percepciones de manera muy cercana a lo que sucede en La novela luminosa cuando habla de la manera en que el "discurso místico transforma al detalle en mito" tras lo que un "destello mantiene fija a la atención. Instante extático, relámpago de insignificancia" (20). El narrador de "La novela luminosa" argumenta que en el centro del placer y de estos destellos está la posibilidad del "desmoronamiento de un yo hipertrofiado en favor de la percepción de la realidad con todas sus dimensiones o, al menos, con todas las dimensiones que estamos capacitados para percibir [...]" (527). De esta manera, estas imágenes tienen múltiples dimensiones y el "yo" se desintegra para percibir la unidad de las cosas en el centro del deseo. Es por esto también que las imágenes son acerca de sucesos particulares en la vida del narrador, sus encuentros con mujeres, con insectos o con animales, pero lo que en verdad intentan capturar es la cualidad genérica y atemporal de las verdades. El narrador, por ejemplo, describe uno de los momentos luminosos diciendo: "No era una mujer, sino todas las mujeres. Una abstracción viviente y presente" (555). En otras palabras, estos acontecimientos luminosos transforman y forman al sujeto por su cualidad universal. El sujeto, en este caso, no tiene otra consistencia que la del momento del encuentro atemporal universal en donde una demanda determina su deseo. No es un sujeto con "bagaje subjetivo" (Zupančič 61) en una situación, sino una instancia que emerge de estas situaciones, del "desmoronamiento de un yo hipertrofiado".

La construcción de un sujeto en y de la narrativa en La novela luminosa es lo que abre la posibilidad de que se pueda crear y transformar el narrador, a través de la escritura. En este sentido, en "Diario de un canalla", el narrador dice con respecto a su escritura y la forma autobiográfica de sus últimas novelas:

Pero no estoy escribiendo para ningún lector, ni siquiera para leerme yo. Escribo para escribirme yo; es un acto de autoconstrucción. Aquí me estoy recuperando, aquí estoy luchado por rescatar pedazos de mí mismo que han quedado adheridos a mesas de operación (iba a escribir de disección), a ciertas mujeres, a ciertas ciudades, a las descascaradas y macilentas paredes de mi apartamento montevideano, que ya no volveré a ver, a ciertos pasajes, a ciertas presencias [...] No me fastidien con el estilo ni con la estructura esto no es una novela, carajo. Me estoy jugando la vida. (25)

Lo que el narrador busca son los pedazos de su ser que se han quedado adheridos a ciertas experiencias del pasado, espacios, o momentos, para lograr construir su subjetividad en el presente, como resultado del acto de la escritura. Necesita tanto las instancias relevantes que a lo largo del tiempo lo han constituido como el acto de auto-construcción en su escritura, en el tiempo verbal del presente progresivo (me

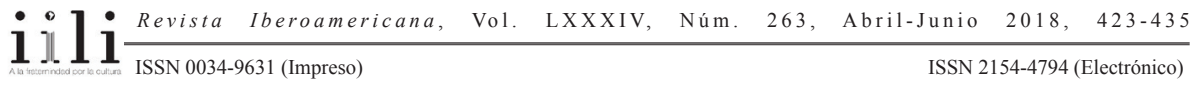


estoy recuperando). Esto implica no sólo la operación quirúrgica y la disección de la experiencia del sujeto, sino también el re-ensamblaje de esas instancias en la imagen de un "yo". Es importante notar que es una imagen, porque esto significa que es una instancia imaginaria, una forma de identificación con el sujeto que está siendo escrito para consolidar las piezas y pedazos de un cuerpo.

Escribir, en este punto, puede servir terapéuticamente como lo que le da consistencia a las piezas del "yo" del narrador, ahora diseccionadas en una narrativa, y que aspiran a formar un sentido del yo, una imagen del yo. Esta "recuperación" es también una "formación" de las piezas de un sujeto en el momento en que se encuentra con su propio ser, en este caso no de manera azarosa, como lo que ha quedado en la mesa de disección. En repetidas ocasiones, Levrero cuenta la historia de que lo que provocó la escritura de sus últimas novelas y su forma autobiográfica fue que lo iban a operar de la vesícula. ${ }^{8}$ El miedo de morir en la operación es lo que le hizo decidir que tenía que escribir sus experiencias trascendentales que, en parte, fueron recuperadas en "La novela luminosa". En la última afirmación tajante de la cita anterior, el narrador dice que está poniendo en juego su vida al "escribirse" en el acto de construir de manera reflexiva a su "yo" y, en este acto de escritura, asume su subjetividad. La estructura de este sujeto es implícita en su decir, en su lenguaje y en todo el proyecto literario. Una vez más, finalmente, el narrador regresa a una reflexión acerca de la forma literaria, dice que lo que escribe no es una novela o, de hecho, que la forma no importa. De esta manera, en el trasfondo del ir y venir de lo profano y lo sagrado, la "recuperación" de estas piezas o "ruinas" como las llama Levrero en otro texto (Discurso vacío 95) es lo que acontece en la escritura de La novela luminosa.

El "retorno al yo" que Levrero lleva a cabo en sus últimas novelas funciona explícitamente como un experimento que empuja los límites de lo que se considera literatura y lo que está más allá de su esfera, abriendo la posibilidad de que la vida sea un material entre otros a ser elaborado estéticamente para lograr la creación de un sujeto que emerge a partir de este proceso estético. Para Levrero la literatura no es acerca de ideas, ${ }^{9}$ sino que es una suerte de teatro, el cuerpo en donde se encuentran

\footnotetext{
Al enfrentar la posibilidad de morir, el autor quiere dejar por escrito sus experiencias trascendentes antes de someterse a la cirugía. Dice en Diario de un canalla: "Han pasado más de dos años; casi tres desde que empecé a escribir aquella novela luminosa, póstuma, inconclusa; dos años, dos meses y unos días desde el día de la operación. El motivo de aquella novela era rescatar algunos pasajes de mi vida, con la idea secreta de exorcizar el temor a la muerte y el temor al dolor, sabiendo que dentro de cierto plazo inexorable iba a encontrarme a merced del bisturí. Bueno; lo cierto es que no he muerto en aquella sala de operaciones" (17).

9 En "La novela luminosa" Levrero dice acerca de las ideas como lo que incita la literatura: "[...] me resisto a la idea, a las ideas -y muy especialmente a la posibilidad de ideas como impulsoras de la literatura" (456).
} 
verdades, y la narrativa de una vida crea los cruces de los hilos que la trascienden, ${ }^{10}$ su subjetividad. La construcción de un sujeto a través de la literatura y la práctica espiritual de incluir-se en la escritura y pensamiento es para Levrero parte de un proyecto más amplio en donde no tiene control, pues va más allá de su individualidad y experiencia. Las experiencias luminosas ya indican este movimiento hacia los hilos que trascienden al sujeto individual, ya que representan el momento del encuentro con una verdad genérica. Se puede decir que este cruce o encuentro con una verdad genérica es el punto en donde lo profano y lo sagrado se articulan. Esta es la manera en que Levrero hace que la literatura sea parte de su vida e implica la construcción de su subjetividad a través de la escritura.

La construcción de la subjetividad a través de la literatura es, acaso, el acto de simbolización y auto-representación en la que Levrero se indaga al narrar. Este procedimiento requiere un tipo de literatura que va más allá de la narrativa y vuelve a las imágenes más cotidianas como, por ejemplo, la forma de un zapato y el contacto con un asiento. Lo inexplicable radica en la experiencia de transformar un sonido en una voz, adscrita a un ser invisible. La "primera comunión” de la literatura de Mario Levrero fue juntar por primera vez la narrativa de los días grises repetitivos y la visión privilegiada de la vida desde los momentos luminosos. El cuerpo de su literatura, de ese modo, representa una manera en la que la literatura se vuelve parte de la vida y la redefine, quitando las capas que limitan la ficción a sus confines en el papel. La novela luminosa es, de muchas formas, la transubstanciación de la literatura en forma de vida.

\section{BiBLIOGRAFÍA}

Astutti, Adriana. "Escribir para después". La máquina de pensar en Mario. Ensayos sobre la obra de Levrero. Ezequiel de Rosso, sel. y pról. Buenos Aires: Eterna Cadencia, 2013. 201-22.

Bataille, Georges. La experiencia interior. Fernando Savater, trad. Madrid: Taurus, 1972. "Lo sagrado". La conjuración sagrada. Ensayos 1929-1939. Sel., trad. y pról. Silvio Mattoni. Buenos Aires: Adriana Hidalgo, 2003. 262-67.

Certeau, Michel. La fábula mística. Siglos XVI-XVII. Jorge López Moctezuma, trad. México: Universidad Iberoamericana/ Instituto Tecnológico y de Estudios Superiores de Occidente, 2004.

Chejfec, Sergio. "Lápices y angustias". La máquina de pensar en Mario. Ensayos sobre la obra de Levrero. Ezequiel de Rosso, sel. y pról. Buenos Aires: Eterna Cadencia, 2013. 191-200.

10 Al respecto, Levrero dice: "La verdad de los hechos es que no somos otra cosa que un punto de cruce entre hilos que nos trascienden, que vienen no se sabe de dónde y van no se sabe adónde, y que incluyen a todos los demás individuos" (El discurso 23).

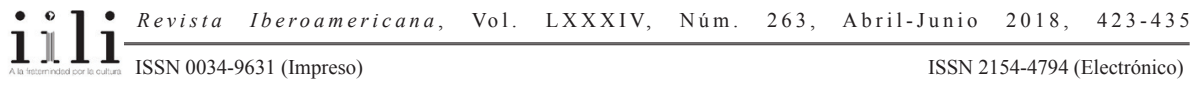


Inzaurralde, Gabriel. “Apuntes sobre La novela luminosa de Mario Levrero". Revista Iberoamericana 78/241 (2012): 1043-65.

Laddaga, Reinaldo. "Un autor visita su casa. Sobre La novela luminosa de Mario Levrero". La máquina de pensar en Mario. Ensayos sobre la obra de Levrero. Ezequiel de Rosso, sel. y pról. Buenos Aires: Eterna Cadencia, 2013. 223-35.

Levrero, Mario y Elvio E. Gandolfo. Un silencio menos. Conversaciones con Mario Levrero. Buenos Aires: Mansalva, 2013.

Diario de un canalla; Burdeos, 1972. Buenos Aires: Mondadori, 2013. El discurso vacío. Montevideo: Ediciones Trilce, 1996. La novela luminosa. Barcelona: Mondadori, 2008.

Rosso, Ezequiel, sel. y pról. La máquina de pensar en Mario. Ensayos sobre la obra de Levrero. Buenos Aires: Eterna Cadencia, 2013.

Žižek, Slavoj. "God Without the Sacred: The Book of Job, the First Critique of Ideology”. New York Public Library Audiovideo, 9 nov. 2010.

The Most Sublime Hysteric. Hegel with Lacan. Thomas Scott-Railton, trad. Cambridge/Malden: Polity, 2014.

Zupančič, Alenka. Ethics of the Real. Kant, Lacan. Londres: Verso, 2000. 
